\title{
Application of the analytic hierarchy process in the selection of traditional food criteria in Vojvodina (Serbia)
}

\author{
Ivana Blešić $1,2^{*} \mathbb{D}$, Marko D. Petrović 2,3 ,Tamara Gajić ${ }^{4}$, Tatiana Tretiakova ${ }^{2}$, Miroslav Vujičić ${ }^{1}$ and \\ Julia Syromiatnikova ${ }^{2}$
}

\begin{abstract}
Vojvodina Province (Northern Serbia) represents a multicultural area inhabited by around thirty nations and national or ethnic groups with their authentic tradition and culture. The gastronomy of Vojvodina has been forming as a reflection of geographic characteristics - natural conditions and social events in this area. The life numerous nations share on this fertile soil of Vojvodina has initiated mutual impact of various customs, which contributed to the creation of a unique and specific Vojvodina cuisine. In this paper, mixed-method research approach was applied. The application of the analytic hierarchy process (AHP) method was preceded by a survey research on the sample of 289 guests in the restaurants on the territory of Vojvodina. The aim of the research was to define the key motives when choosing a traditional Vojvodina dish. In the second stage, AHP model was used for ranking factors significant for choosing traditional food by 29 experts in the field of hospitality and gastronomy. The result shows that Sensory appeal is the most important criterion for choosing traditional food in restaurants by the experts, followed by Health concern, and Familiarity.
\end{abstract}

Keywords: Traditional food, Consumer motives, Experts' choice, Analytic hierarchy process (AHP), Vojvodina

\section{Introduction}

The Autonomous Province of Vojvodina is located in the northern part of the Republic of Serbia in the Pannonian Plain, encompassing $24.3 \%$ of the country's territory (i.e., $21,506 \mathrm{~km}^{2}$ ). The northern province is intersected by three big navigable rivers (the Danube, the Tisa, and the Sava), which divide its territory into three clearly distinctive wholes: on the far east there is Banat, on the northwest-Bačka, and on the southwest-Srem [1]. According to the last census from 2011, the AP Vojvodina has a population of $1,931,809$, or $21.56 \%$ of the total population of the Republic of Serbia. The Serbs represent the majority

\footnotetext{
*Correspondence: ivana.blesic@gmail.com

${ }^{1}$ Department of Geography, Tourism and Hotel Management, Faculty of Sciences, University of Novi Sad, Trg Dositeja Obradovića 3, 21000 Novi Sad, Serbia

Full list of author information is available at the end of the article
}

of its population (67\%), followed by the Hungarians (13\%), Slovaks (3\%), Croats (2\%), Roma (2\%), Romanians (1\%), Montenegrins (1\%), and other smaller ethnic groups, including Bunjevci, Ruthenians, Yugoslavs, Macedonians, Ukrainians, Germans, Albanians, Slovenians, Bulgarians, and others [2] (Fig. 1).

All the nations that came to live in Vojvodina brought their national features with them, both in culture and in the way of life, and in the food as well. That is the reason why the cuisine of Vojvodina is characterized by a great diversity. In Bačka and Srem, there is a strong impact of the Hungarians, Germans, Croats, Slovaks, and Ruthenians. In Banat, besides the influence of the Hungarians, Germans, and Slovaks, the forming of Vojvodina cuisine was greatly contributed by the Romanians as well. However, it may be concluded that the greatest impact was of the German and Hungarian cuisines [3]. The influence of original author(s) and the source, provide a link to the Creative Commons licence, and indicate if changes were made. The images or other third party material in this article are included in the article's Creative Commons licence, unless indicated otherwise in a credit line to the material. If material is not included in the article's Creative Commons licence and your intended use is not permitted by statutory regulation or exceeds the permitted use, you will need to obtain permission directly from the copyright holder. To view a copy of this licence, visit http://creativecommons.org/licenses/by/4.0/. 


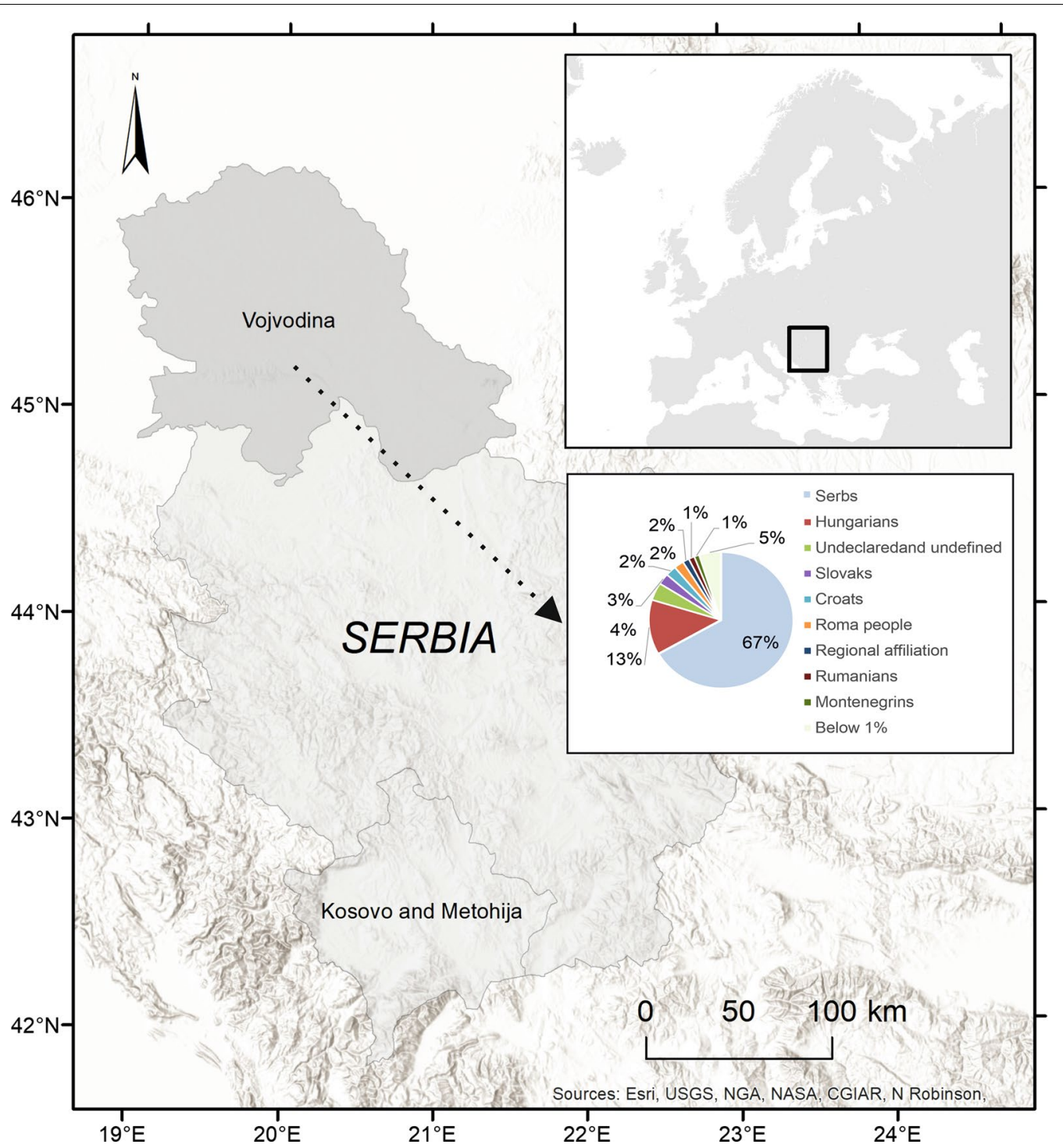

Fig. 1 Map showing the geographical position of Vojvodina (Serbia) within Europe and ethnic structure of the population of Vojvodina

these national cuisines on the development of a unique Vojvodina cuisine can be seen in the names of many dishes and other gastronomic terms that were adopted from the German language, such as "fruštuk" (Das Frühstück) for breakfast, "jauzna" (Die Jause) for snack, "foršpajz" (Die Vorspeise) for an appetizer, "rindflajš" (Die Rindfleisch) for boiled beef, "cušpajz/varivo" (Die Zuspeise) for a vegetable dish, as well as strudel, doughnuts and dumplings, or from the Hungarian language such as "perkelt" (pörkölt) for meat fried in its own juices, "gulaš" (gulyás) for goulash, and "paprikaš" (paprikás) for stew [4]. Table 1 shows ingredients, cooking type, and preparation time of the traditional Vojvodina dishes. The traditional Vojvodina dishes are prepared with the ingredients which have high nutritional values. The preparation method, which mainly includes boiling and simmering, is in accordance with the principles of a healthy diet [5]. The highest value of proteins in $100 \mathrm{~g}$ of a prepared dish can be found in "rindflajš" and then in "riblji paprikaš." These dishes are also the leaders in the content of fats, as well as in calories. The highest content of the total carbohydrates is in "ćuretina sa mlincima" (Table 2).

The authentic life of the past centuries in Vojvodina can be experienced most on "salaši." "Salaš" represents an agricultural property, i.e., a house with its farmstead in the fields, surrounded by vast arable land. The building of "salaši" started around the middle of the eighteenth century [6]. Even though thousands of 
Table 1 Traditional Vojvodina dishes (ingredients, cooking type, and preparation time). Source: [8]

\begin{tabular}{|c|c|c|c|}
\hline Traditional Vojvodina dishes & Ingredients (for 4 servings) & Cooking & Timing \\
\hline Riblji paprikaš (Fish stew) & $\begin{array}{l}2 \mathrm{~kg} \text { of carp cut into steaks, } 3 \text { I water, } 1 \mathrm{~kg} \text { chopped onions, } 20 \mathrm{~g} \\
\text { ground sweet peppers, } 200 \mathrm{ml} \text { tomato juice, } 15 \mathrm{~g} \text { salt, } 2 \mathrm{~g} \text { fine } \\
\text { ground black pepper }\end{array}$ & Boiling & $60 \mathrm{~min}$ \\
\hline Rindflajš (Boiled beef with vegetables) & $\begin{array}{l}800 \mathrm{~g} \text { beef, } 3 \text { I water, } 400 \mathrm{~g} \text { carrots, } 400 \mathrm{~g} \text { potatoes, } 200 \mathrm{~g} \text { parsnip, } \\
200 \mathrm{~g} \text { parsley, } 200 \mathrm{~g} \text { celery, } 15 \mathrm{~g} \text { salt, } 3 \mathrm{~g} \text { peppercorn }\end{array}$ & Boiling & $120 \mathrm{~min}$ \\
\hline Perkelt (Drier variety of goulash) & $\begin{array}{l}700 \mathrm{~g} \text { veal, } 700 \mathrm{~g} \text { chopped onions, } 3 \mathrm{~g} \text { minced garlic, } 10 \mathrm{~g} \text { ground } \\
\text { sweet peppers, } 3 \mathrm{~g} \text { ground cayenne peppers, } 300 \mathrm{ml} \text { red wine, } \\
250 \mathrm{ml} \text { tomato juice, } 3 \mathrm{~g} \text { fine ground black pepper, } 10 \mathrm{~g} \text { salt, } 3 \\
\text { bay leaves, } 100 \mathrm{ml} \text { sunflower oil, } 200 \mathrm{ml} \text { water }\end{array}$ & Simmering and boiling & $70 \mathrm{~min}$ \\
\hline Curetina sa mlincima (Turkey with pasta tatters) & $\begin{array}{l}400 \mathrm{~g} \text { turkey breasts, } 200 \mathrm{ml} \text { sour cream, } 30 \mathrm{ml} \text { olive oil, } 100 \mathrm{~g} \\
\text { grated hard cheese, } 300 \mathrm{~g} \text { pasta tatters, } 1 \text { I broth }\end{array}$ & Boiling and baking & $35 \mathrm{~min}$ \\
\hline Sekelji gulaš (Szekely goulash) & $\begin{array}{l}500 \mathrm{~g} \text { pork, } 1 \mathrm{~kg} \text { sauerkraut, } 300 \mathrm{~g} \text { sausages, } 300 \mathrm{~g} \text { chopped } \\
\text { onions, } 100 \mathrm{ml} \text { sunflower oil, } 6 \mathrm{~g} \text { salt, } 3 \mathrm{~g} \text { fine ground black pep- } \\
\text { per, } 7 \mathrm{~g} \text { ground sweet peppers, } 2 \mathrm{~g} \text { ground cayenne peppers, } \\
400 \mathrm{ml} \text { sour cream }\end{array}$ & Simmering and boiling & $70 \mathrm{~min}$ \\
\hline
\end{tabular}

Table 2 Proximate nutritional values of the traditional Vojvodina dishes ${ }^{*}$

\begin{tabular}{llllll}
\hline Traditional Vojvodina dishes & $\begin{array}{l}\text { Energy } \\
(\mathbf{k c a l} / \mathbf{1 0 0} \mathbf{~ g})\end{array}$ & $\begin{array}{l}\text { Energy } \\
\mathbf{( k J / 1 0 0 ~ g )}\end{array}$ & $\begin{array}{l}\text { Total fat } \\
\mathbf{( g / 1 0 0 ~} \mathbf{~})\end{array}$ & $\begin{array}{l}\text { Total carbohydrate } \\
\mathbf{( g / 1 0 0 ~ g ) ~}\end{array}$ & $\begin{array}{l}\text { Protein } \\
(\mathbf{g} / \mathbf{1 0 0} \mathbf{~ g})\end{array}$ \\
\hline Riblji paprikaš (Fish stew) & 191 & 799 & 12.5 & 8.2 & 15 \\
Rindflajš (Boiled beef with boiled vegetables) & 260 & 1088 & 12 & 14.5 & 37 \\
Perkelt (Drier variety of goulash) & 178 & 745 & 6 & 4 & 12 \\
Ćuretina sa mlincima (Turkey with pasta tatters) & 159 & 665 & 6.7 & 16.4 & 8.1 \\
Sekelji gulaš (Szekely goulash) & 117 & 490 & 7.7 & 3.05 & 8.3 \\
\hline
\end{tabular}

* Note: Calculated on the basis of $[5,9,10]$ :

"salaši" were demolished after the Second World War, today, there are enough "salaši" in Vojvodina to be the reminders of the past times [7]. Some of them still work as agricultural properties, and 65 "salaši" have been transformed into tourist sites and specific restaurants of the traditional Vojvodina cuisine [8].

The conducted research had two basic goals. The first was the identification of the guests' key motives for choosing the traditional Vojvodina cuisine in ethno restaurants on the territory of Vojvodina ("salaši"). The second aim of this paper was to research the most significant criteria for choosing the traditional dishes, as well as to identify the best and most authentic traditional dish by using the AHP method and by examining the experts' attitude.

Gastro-tourism has been popular in the world for several decades, but only recently in Vojvodina, with still not enough awareness of the employees in tourism industry about its benefits for the local and regional development. In the recent development policies and concepts that referred to the tourism development, gastronomy, i.e., the dishes prepared in the traditional way, were not given the adequate development role. Moreover, the subjects of the studies that dealt with
Vojvodina cuisine were mainly only one of the national cuisines that the unique.

Vojvodina cuisine consists of. Thus, this study represents a novelty in the scientific literature in this field for two reasons: first, it researches the key motives for choosing a traditional Vojvodina dish in restaurants, and second, it investigates the attitudes of experts in the field of hotel management and gastronomy regarding the factors that decide on the most authentic dish.

\section{Literature review}

The term "traditional food" is defined as "...a product frequently consumed or associated with specific celebrations and/or seasons, usually passed on from one generation to another, made accurately in a specific way according to the gastronomic heritage, with little or no processing/manipulation, distinguished and known because of its sensory properties and associated with a certain local area, region or country" [11, p. 348]. According to [12], a traditional food product belongs to a defined space, and it is part of a culture that implies the cooperation of the individuals performing in that region.

Many studies have analyzed the concept of traditional food [11, 13, 14], traditional food consumer acceptance 
and preference [15-22], its sensory characteristics [23$26]$, or the impact of traditional food on health [27-30].

In the research related to the motives for choosing food, the work of Steptoe, Pollard, and Wardle is one of the essential starting points [31]. They classified food choice motives into nine dimensions: Health, Mood, Convenience, Sensory appeal, Natural content, Price, Weight control, Familiarity, and Ethical concern. The Food Choice Questionnaire was widely used by scholars to explore choice motives of consumers with different cultures and food products [32-39]. Several studies, like this one, focused on traditional food [40-43].

Traditional food, in relation with the development of tourism and local economy, was the subject of interest in several research papers [44-46]. As part of the tourist experience, eating traditional local food is a way of breaking with everyday routine [44]. Moreover, food diversity is a core theme in destination marketing [46]. Multiculturalism has the influence on the variety of the gastronomic offer in Vojvodina and made it attractive and interesting for the majority of consumers who try traditional specialties. The Autonomous Province of Vojvodina, which represents one multiethnic area and fertile plain, has numerous potentials for the development of rural, cultural, and gastro-tourism [47].

\section{Methodology}

The research itself consists of several phases (Fig. 2). The pre-study phase included literature and restaurants' menus review in order to a) select an adequate questionnaire to measure food choice and b) choose the five traditional dishes that are most present in restaurants. Potential motives for choosing traditional food were almost entirely based on the Food Choice Questionnaire [31]. Only the most appropriate and relevant items for the case of traditional food were included. In the first phase, the authors interviewed a focus group of eight experts constituted by academic researchers and managers of traditional restaurants in Vojvodina to refine the selected items. As a result, the ethical concern FCQ dimension was not included in the questionnaire. The results of the performed interview pointed that the items which contain ethnical concern factor were not adequate for interviewing guests in restaurants. Eight FCQ dimensions were included in the research: weight control, price, mood, convenience, natural content, health, sensory appeal, and familiarity. The total number of items was 33 . The second phase was conducted for evaluating the motives that determine guests' perception of traditional Vojvodina food. In that context, paper and pen survey was used in order to collect data from the guests in the selected restaurants which offer dishes of the traditional Vojvodina cuisine. The questionnaire was distributed in 50 traditional restaurants in all parts of Vojvodina, while the data were obtained from the total of 42 restaurants. The survey was conducted from January till August 2019, and guests' participation was anonymous and voluntary. A five-point Likert scale (strongly disagree $=1$ to strongly agree $=5$ ) was used to assess all the items.

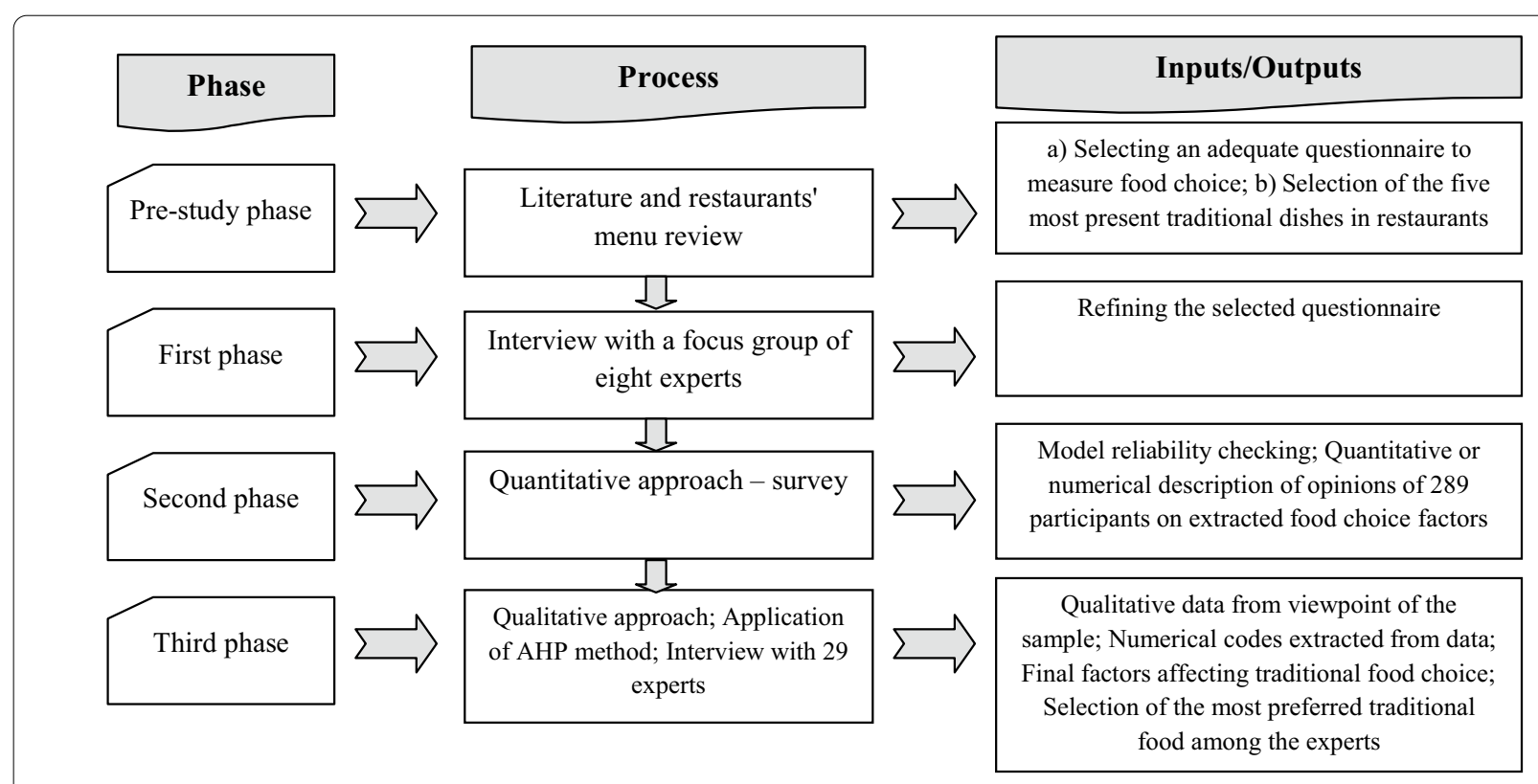

Fig. 2 A graphical scheme of study design 
In the third phase, the AHP model was used for ranking the obtained motives significant for choosing traditional food. A total of 29 experts evaluated the importance of each factor in relation to other factors considered. Data analysis was conducted through the use of Statistical Package for Social Sciences (SPSS.23) and Expert Choice 2000 software packages.

One of the most famous methods used in the multicriteria decision-making is the analytic hierarchy process (AHP). The analytic hierarchy process (AHP) is a systematic approach developed by Saaty [48]. It is most often applied in solving complex problems that consist of numerous elements which contain aims, criteria, sub-criteria, and alternatives. In this technique, the problem is hierarchically broken down into the abovementioned elements in the top-to-bottom direction. Using answers collected from the respondents, the AHP gradually compares alternatives and then measures their impact on the final decision-making goal. The goal of the AHP method is to break down even the most complex problem into the hierarchy for the aim of an easier analysis. Such an organization shows that AHP is a multi-criteria technique. All the parts of the hierarchy are interconnected, so it is very easy to notice how a change of one factor affects others [49]. It gained its popularity by proving as a useful tool for the support in making decisions in such a way that it enables a decision maker to prioritize and make the best decisions.

The specific comparative technique which used AHP method determines the preferences for the set of elements at a given level of a decision-making hierarchy by employing pairwise comparisons of these elements, with respect to the elements at the higher level. Here, Saaty's scale [48] was used, given as $1,3,5,7,9$, where 1 denotes equal importance and 9 shows the absolute importance of one element over another (Table 3). If element $i$ is more important than element $y$, then a relevant index value is assigned in the matrix A. But if the judgment is that $y$ is more important than $i$, the reciprocal value of the relevant index is assigned to the matrix A. The results of all the comparisons are placed in positive reciprocal quadratic matrices. The next stage in the AHP method is to calculate the eigenvector, using the standard AHP method, for each matrix. The so-called local priority vector is calculated using the principal eigenvector of a comparison matrix, as suggested by Saaty [48]. The section below shows how this takes place in more detail.

The result of the comparison of the elements $i$ and $y$ is placed in matrix $\mathrm{A}$ in the position a:
Table 3 Saaty's scale for pairwise comparisons in AHP. Source: [50]

\begin{tabular}{ll}
\hline $\begin{array}{l}\text { Intensity of importance on } \\
\text { an absolute scale }\end{array}$ & Definition \\
\hline 1 & Equal importance \\
3 & Moderate importance of one over another \\
5 & Essential or strong importance \\
7 & Very strong importance \\
9 & Extreme importance \\
$2,4,6,8$ & Intermediate values between the two \\
& adjacent judgments \\
\hline
\end{tabular}

$$
A=\left[\begin{array}{cccc}
a_{11} & a_{12} & \ldots & a_{1 n} \\
a_{21} & a_{22} & \ldots & a_{2 n} \\
\cdot & \cdot & \ldots & \cdot \\
\cdot & \cdot & . & \cdot \\
a_{n 1} & a_{n 2} & \ldots & a_{n n}
\end{array}\right]
$$

The reciprocal value of the results of the comparison is placed on the position $\mathrm{a}_{\mathrm{yi}}$ to preserve the consistency of the judgment. The respondent is asked to compare $n$ elements and place the results in matrix A. After all the pairwise comparison matrices have been formed, the vector of weights, $w=\left[w_{1}, w_{2}, \ldots, w_{n}\right]$, is then computed on the basis of Saaty's eigenvector procedure. The computation of the weights involves two steps. First, the pairwise comparison matrix, $A=\left[a_{i j}\right]_{n \times n}$, is normalized by Eq. (1), and then the weights are calculated using Eq. (2).

Normalization:

$$
a_{i j}^{*}=\frac{a_{i j}}{\sum_{i=1}^{n} a_{i j}}
$$

Weights calculation:

$$
w_{i}=\frac{\sum_{j=1}^{n} a \times i j}{n}
$$

for all $i=1,2, \ldots, n$.

Saaty [48] showed that there is a relationship between the vector weights, $w$, and the pairwise comparison matrix, A. The final stage of the evaluation of the decision-making process is to calculate the consistency ratio (CR) in order to determine how consistent the judgments are between the respondents, and thus to consider whether the results from multiple respondents are generalizable. The closer $\lambda_{\max }$ is to $n$, the more consistent the judgments are between the respondents. The difference $\lambda_{\max }-n$ can be used to measure the level of inconsistency in responses, but instead of using this, Saaty defined 
a consistency index $(\mathrm{CI})$ which is calculated according to the formula $\left(\lambda_{\max }-n\right) /(n-1)$. Finally, the CR can be calculated from the ratio of the $\mathrm{CI}$ and the random index (RI) according to formula CR $=\mathrm{CI} / \mathrm{RI}$, as defined by Saaty [48] and Saaty [50]. RI represents the random index derived from numerous randomly generated $n \times n$ matrices. If the CR is less than 0.10 , the result is sufficiently accurate and there is no need for adjustments in comparison or for repeating the calculation. If the CR is much in excess of 0.10 the judgments are untrustworthy and the results should be reanalyzed to determine the reasons for the inconsistencies.

AHP model has been widely used in hospitality studies in a variety of contexts [20,51-56]. However, AHP model is rarely used for multi-criteria decision-making in choosing traditional dishes in restaurants.

The aim of this paper is the selection of the best traditional Vojvodina dish from the experts' point of view. They are university professors in the fields of hotel management and gastronomy, managers with master's degrees in gastronomy, as well as the managers of restaurants that have traditional Vojvodina dishes in their offer. In order to evaluate criteria weight for the selection of key factors that are important for the quality and authenticity of traditional dishes from the experts' point of view, the authors first developed hierarchy-structured model (Fig. 3) and then applied AHP method. Figure 3 shows the hierarchal structure of the problem which is the subject of this paper. The overall goal of the study was the identification of the most preferred traditional food. The criteria (blue outline) are the factors (Sensory appeal, Health concern, Mood, Familiarity, Convenience, and Price), and sub-criteria (orange outline) are the items obtained as a result of the performed explorative factor analysis (Table 5). The alternatives (green outline) are the following traditional dishes of Vojvodina cuisine: "Riblji paprikaš," "Rindflajšs," "Perkelt," "Curetina sa mlincima," and "Sekelji gulaš" (Figs. 5, 6, 7, 8, 9 in "Appendix"). The alternatives were selected by the authors according to the analysis of the presence of the traditional Vojvodina dishes in the menus of 65 restaurants on the territory of Vojvodina. The research includes the five most present dishes from the group of main dishes.

The interviews were conducted by the authors during January and February 2021. Initially, 40 experts were invited to participate in the research: 11 refused to participate because they thought filling questionnaires is time-consuming. The final sample included 29 experts: 9 managers of the restaurants of traditional Vojvodina cuisine, 15 managers with master's degrees in hotel management and gastronomy, and five university professors in the field of hotel hospitality and gastronomy from the University of Novi Sad, the Department of geography, tourism and hotel management.

The sample size selection for AHP survey is fitting for an appropriately selected small sample size and lends itself to the use of in-depth structured interviews which is useful for research focusing on a specific issue [58]. In collective decision-making with AHP, groups consisting of two to five people are defined as small-sample groups, while groups consisting of more than five people are defined as large-sample groups [59].

\section{Results}

\section{Study sample}

The total sample consists of 289 guests. There are a higher number of women in the sample $(59.17 \%)$. The main age group was between 41 and 50 years of age, thus making $39.79 \%$ of the whole sample. Most of the respondents have finished faculty or college (48.79\%). Regarding their occupation, the majority of the respondents are employed (75.78\%) (Table 4).

\section{Exploratory factor analysis}

The obtained data were factor analyzed using the principal component method and Promax rotation procedure in order to extract the factors of motive attributes. All the factors with eigenvalue greater than 1 and with factor loadings more than 0.5 were retained.

The results of the factor analysis, which suggested a sixfactor solution, included 21 items from the original FCQ and explained $62.99 \%$ of the variance. Twelve items were deleted due to low factor loadings. The Kaiser-MeyerOlkin (KMO) overall measure of sampling adequacy was 0.78 [60], and Bartlett's test of sphericity was significant $(p=0.001)$.

The first factor was labeled "Sensory appeal." This factor explained $15.002 \%$ of the total variance with a reliability coefficient of 0.701 . The second factor was "Health concern" explaining $13.236 \%$ of the total variance with a reliability coefficient of 0.720 . The third factor was labeled "Familiarity" and explained $10.125 \%$ of the variance with a reliability coefficient of 0.852 . The fourth factor, labeled "Mood," accounted for $9.102 \%$ of the variance with a reliability coefficient of 0.865 . The fifth, "Price," explained $8.320 \%$ of the total variance, indicating a reliability coefficient of 0.798. The sixth factor, labeled "Convenience," accounted for $7.201 \%$ of the variance with a reliability coefficient of 0.712. Cronbach's $\alpha$ values for each factor were greater than 0.7 . This confirms that the scales of the obtained questionnaire have considerable reliability [61]. Table 5 shows the results of the factor analysis. 


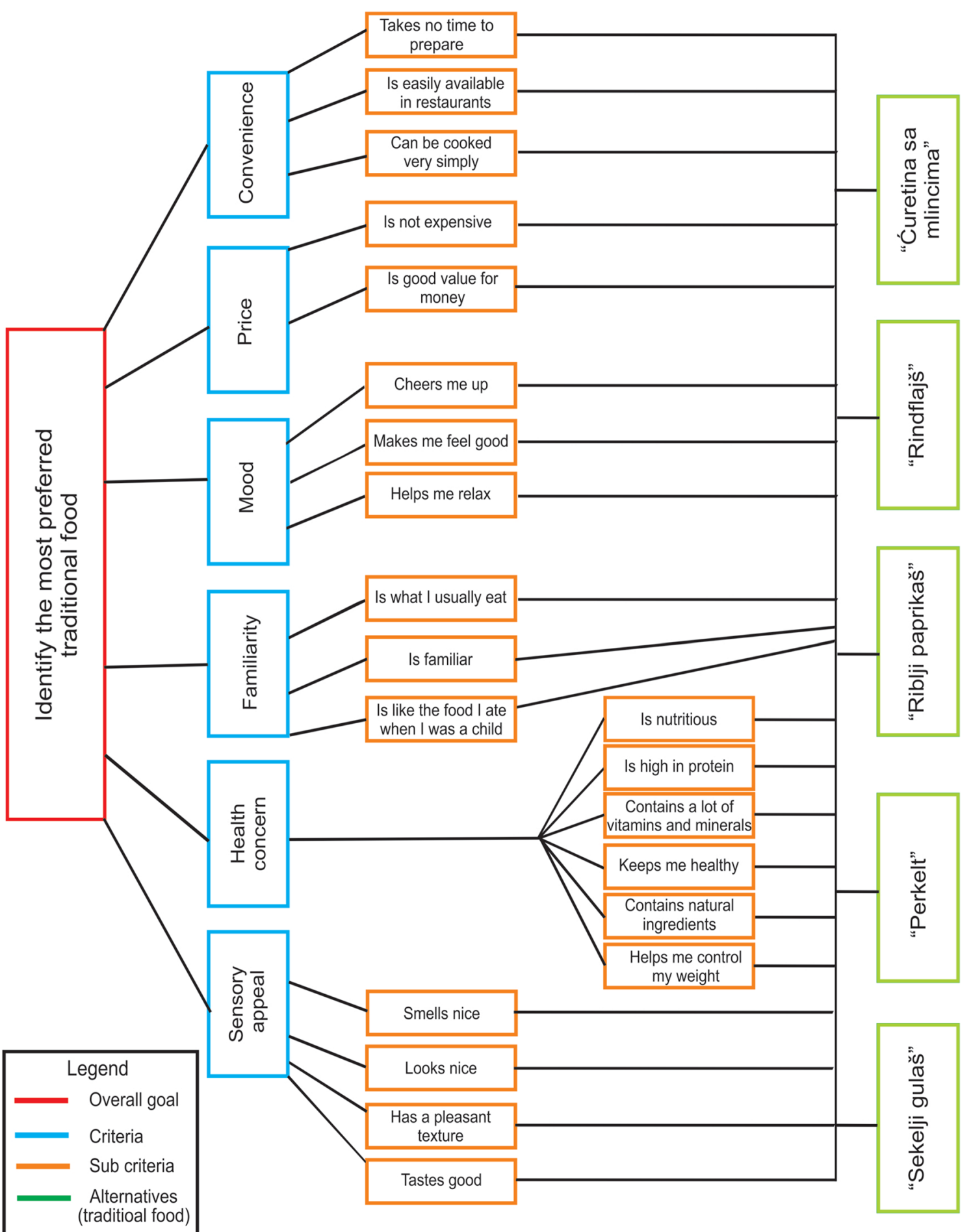

Fig. 3 Hierarchical structure of the problem

\section{Results of the application of the AHP method}

The results show that at the first level of the hierarchy the most important criteria influencing the choice of traditional food is Sensory appeal (0.313), followed by Health concern (0.294), Mood (0.170), and Familiarity (0.122), while the least important are Convenience $(0.051)$ and Price (0.050). Consistency ratio (CR) is 0.01 , which indicates that the study is reliable and accurate and there is 
Table 4 Sociodemographic characteristics of the respondents $(N=289)$

\begin{tabular}{llll}
\hline Gender (\%) & & Age (\%) \\
Male & 40.83 & $21-30$ & 2.08 \\
Female & 59.17 & $31-40$ & 29.06 \\
& & $41-50$ & 39.79 \\
& & $51-60$ & 16.27 \\
& & $61 \geq$ & 12.80 \\
Education (\%) & & Occupation (\%) & \\
Secondary school & 30.45 & Student & 1.38 \\
Faculty/College & 48.79 & Employed & 75.78 \\
M.Sc/ Ph.D. degree & 20.76 & Retired & 13.15 \\
& & Unemployed & 9.69 \\
\hline
\end{tabular}

Source: Data analyzed in Statistical Package for Social Sciences (SPSS.23)

no need for a new evaluation of the weight criteria. The combination of all the responses of the experts leads to an analysis of all individual items on the second level of the hierarchy, and the obtained weight coefficients indicate the most dominant ones to those least dominant when it comes to sub-criteria influencing the criteria for choosing traditional Vojvodina food (Table 6).

Figure 4 presents the overall weights or priority in the selection of traditional food in this study. Based on Fig. 4, the results show that "Riblji paprikaš" (0.293) is the most preferred traditional food among the experts with respect to all decision criteria which are Sensory appeal, Health concern, Mood, Familiarity, Convenience, and Price. The preference of the traditional food is followed by "Rindflajš" (0.291), "Perkelt" (0.166), "Curetina sa mlincima" (0.151), and "Sekelji gulaš" (0.099).

\section{Discussion and conclusion}

This paper aims to determine the priority of decisionmaking criteria in the selection of traditional Vojvodina food among the experts using the AHP model. Based on the results, Sensory appeal plays the major role in the decision-making process to choose traditional food, followed by the Health concern, Mood, Familiarity, Convenience, and Price. The Sensory appeal, Health, Convenience, and Price are the most important factors in the original FCQ [31]. The Price was the most

Table 5 Results of factor analysis

\begin{tabular}{|c|c|c|c|c|c|}
\hline \multicolumn{6}{|c|}{ It is important to me that the traditional food I eat in a restaurant: } \\
\hline Extracted factors & Items & Factor loading & Eigenvalue & $\begin{array}{l}\text { Variance } \\
\text { explained }\end{array}$ & Cronbach's a \\
\hline \multirow[t]{4}{*}{ Sensory appeal } & Smells nice & 0.820 & 5.325 & 15.002 & 0.701 \\
\hline & Looks nice & 0.801 & & & \\
\hline & Has a pleasant texture & 0.789 & & & \\
\hline & Tastes good & 0.756 & & & \\
\hline \multirow[t]{6}{*}{ Health concern } & Is nutritious & 0.780 & 3.156 & 13.236 & 0.720 \\
\hline & Is high in protein & 0.752 & & & \\
\hline & Contains a lot of vitamins and minerals & 0.763 & & & \\
\hline & Keeps me healthy & 0.589 & & & \\
\hline & Contains natural ingredients & 0.620 & & & \\
\hline & Helps me control my weight & 0.590 & & & \\
\hline \multirow[t]{3}{*}{ Familiarity } & Is what I usually eat & 0.722 & 1.982 & 10.125 & 0.852 \\
\hline & Is familiar & 0.714 & & & \\
\hline & Is like the food I ate when I was a child & 0.691 & & & \\
\hline \multirow[t]{3}{*}{ Mood } & Cheers me up & 0.802 & 1.874 & 9.102 & 0.865 \\
\hline & Makes me feel good & 0.785 & & & \\
\hline & Helps me relax & 0.744 & & & \\
\hline \multirow[t]{2}{*}{ Price } & Is not expensive & 0.620 & 1.432 & 8.320 & 0.798 \\
\hline & Is good value for money & 0.612 & & & \\
\hline \multirow[t]{3}{*}{ Convenience } & Takes no time to prepare & 0.715 & 1.333 & 7.201 & 0.712 \\
\hline & Is easily available in restaurants & 0.625 & & & \\
\hline & Can be cooked very simply & 0.538 & & & \\
\hline
\end{tabular}

Source: Data analyzed in Statistical Package for Social Sciences (SPSS.23) 
Table 6 Total weight values for factors (criteria) and individual items (sub-criteria)

\begin{tabular}{|c|c|}
\hline Factors (criteria) & Items (sub-criteria) \\
\hline \multirow[t]{4}{*}{ Sensory appeal (0.313) } & Tastes good (0.435) \\
\hline & Smells nice (0.298) \\
\hline & Looks nice $(0.143)$ \\
\hline & Has a pleasant texture (0.124) \\
\hline \multirow[t]{6}{*}{ Health concern $(0.294)$} & Keeps me healthy $(0.286)$ \\
\hline & Contains natural ingredients $(0.208)$ \\
\hline & Is high in protein $(0.196)$ \\
\hline & $\begin{array}{l}\text { Contains a lot of vitamins and minerals } \\
(0.168)\end{array}$ \\
\hline & Is nutritious (0.082) \\
\hline & Helps me control my weight (0.061) \\
\hline \multirow[t]{3}{*}{ Mood (0.170) } & Cheers me up (0.408) \\
\hline & Makes me feel good (0.400) \\
\hline & Helps me relax (0.192) \\
\hline \multirow[t]{3}{*}{ Familiarity (0.122) } & Is familiar (0.480) \\
\hline & $\begin{array}{l}\text { Is like the food I ate when I was a child } \\
(0.296)\end{array}$ \\
\hline & Is what I usually eat $(0.224)$ \\
\hline \multirow[t]{3}{*}{ Convenience (0.051) } & Is easily available in restaurants ( 0.581$)$ \\
\hline & Takes no time to prepare $(0.256)$ \\
\hline & Can be cooked very simply (0.163) \\
\hline \multirow[t]{2}{*}{ Price $(0.050)$} & Is good value for money $(0.673)$ \\
\hline & Is not expensive $(0.327)$ \\
\hline Overall inconsistency: 0.01 & \\
\hline
\end{tabular}

Source: Data analyzed in Expert Choice 2000 program

important food choice motive in Spain, Greece, Ireland, Portugal, and the Netherlands, Sensory appeal was the first for Norway, Germany, and the UK, while Natural content was the most important food choice motive in Poland [34]. Sensory appeal, Natural content, and Price are the important motivational food choice factors for Turkish population [36]. Based on the research conducted among Chinese consumers [41], Sensory appeal was a direct and strong motive not only for buying traditional Chinese food, but European food as well. Sensory pleasure, in terms of the characteristics such as good taste, nice smell, appearance, and texture, is considered to be of great importance for consumer food preferences. Similar results were obtained among the respondents from European countries by Januszewska et al. who examined the differences in food choice factors among the respondents from four countries (Belgium, Hungary, Romania, and the Philippines) [33]. The respondents from European countries defined Sensory appeal of food as the most important factor in their daily food choice, while the factor related to health was the key one for the respondents from the Philippines. Similar to this research, Verbeke states that, generally, Health concern was recognized as one of the most important motives in the choice of food [62]. In contrast to this study, the research of the key elements for choosing food conducted by Fotopoulos et al. was done on the sample of 997 Greek households, and it showed that Natural content was the most important factors for the respondents, followed by [63]. The research results conducted in the restaurants in Vojvodina point out that taste is the characteristic which most affects the perception of the quality of food. Out of the total of 600 respondents, $83 \%$ of them believe that Vojvodina traditional dishes are very tasty [64]. The significance of sensory characteristics for the perception of the quality of dishes was also confirmed by other authors [65, 66]. The dominant significance of the criteria Sensory

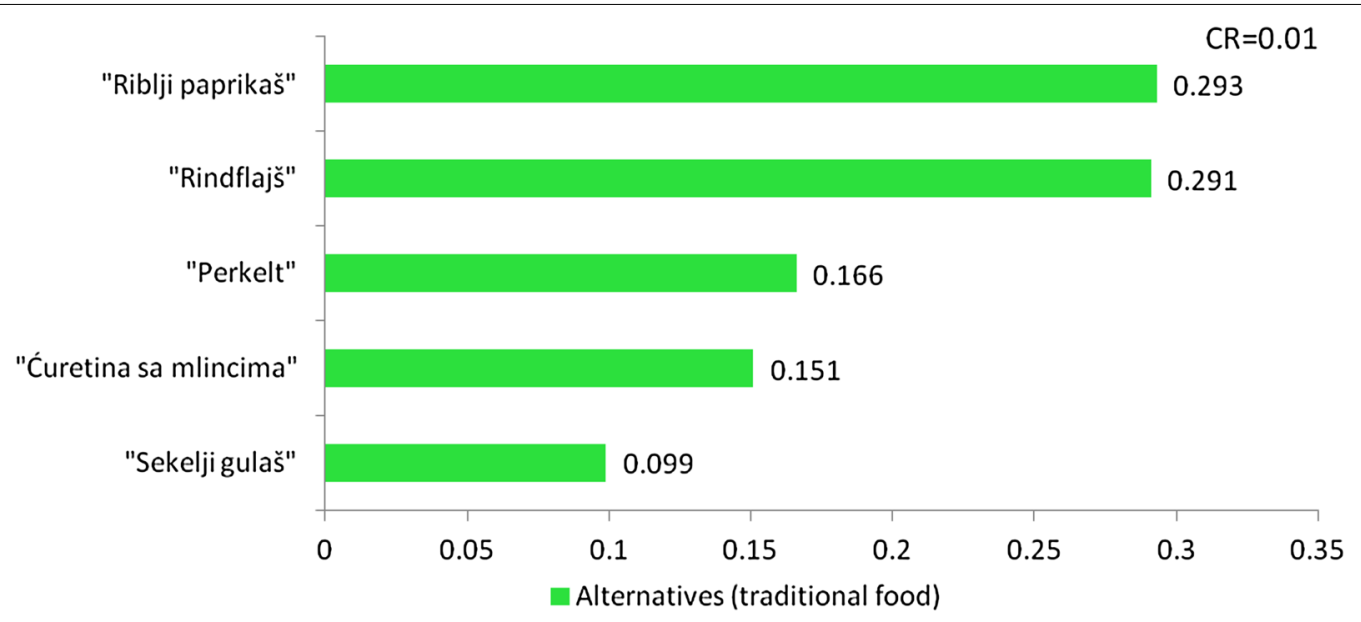

Fig. 4 Total weight values for the alternatives. Source: data analyzed in Expert Choice 2000 program 
appeal and Health concern was also confirmed by Ting et al. who point out that only sensory appeal and health concern are found to have positive effect on the intention to consume Dayak food by the Malaysians [40]. Mood factor contains the items that are related to the general mood, relaxation, and stress control. Familiarity factor includes the items related to the preference to the dishes the respondents are used to and that they are familiar to them. Relatively high weight values of these criteria suggest that the mood and the choice of familiar food may influence the choice of food.

The least significant impact on choosing a dish was found in Convenience, which relates to the preparation and availability of traditional food, and Price. The cost of food is an important criterion in decision-making when buying food in the population with low income [31, 34]. Since the criteria were assessed by the experts who do not belong to the population with low income (professors employed at the University of Novi Sad, managers with MA degrees in hotel management and gastronomy, and restaurant managers), it is understandable that Price was the least important factor when choosing a dish. Other studies have confirmed that Familiarity and Ethical concern were the least important in European countries [33, 34], and Ethical concern and the Weight control were the least important food choice motives for Turkish population [36].

Riblji paprikaš, which was the best rated by the experts, represents a cult dish in Vojvodina, especially in the area of the Upper Danube area (in the upper course of the Danube). Riblji paprikaš is usually cooked in the nature, in a pot, and the skill of cooking riblji paprikaš has become a part of a cult ritual. Every chef also has their special culinary secret and is sure it is that secret that makes their paprikaš the best. A special merit for the popularization of the cult of this dish goes to the Danube "čardas" (specialized fish restaurants by the river), where the best paprikaš is served.

The hierarchy of factors for choosing traditional food provides useful insight for restaurant management and marketing (e.g., branding strategy, improvement of promotion, and sale of gastronomic products). Moreover, the insight into the combination of the criteria that affect the choice of Vojvodina dishes, as well as the overview of the selected alternatives, will help the enhancement and preservation of the unique national cuisine which is the result of a long-lasting synergy of culture and customs of a large number of ethnic groups on this territory.

Further research will be focused on the survey of different samples (foreign tourists, domestic tourists, local population) in order to examine the key motives for choosing a traditional dish based on different sociodemographic characteristics of the respondents. Also, the analytic hierarchy process (AHP) will be applied in the multi-criteria decision-making for choosing traditional Vojvodina dishes from the groups of appetizers and desserts.

\section{Appendix}

See Figs. 5, 6, 7, 8, and 9.

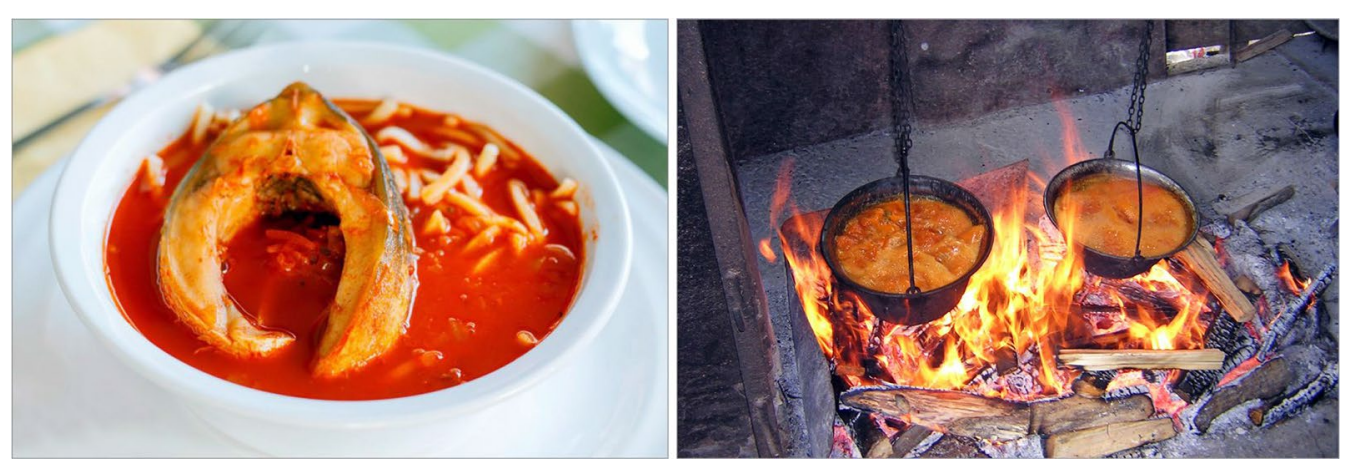

Fig. 5 Riblji paprikaš, Fish stew has its gastronomic roots from the Hungarian cuisine. It is made of various kinds of fish, but carp is the most frequent and irreplaceable ingredient. Besides carp, pieces of pike, catfish, or starlet, can be added, to taste. Besides fish, the stew also contains chopped onions, hot and sweet peppers, salt, and cooked tomato. All the ingredients are put in the pot which is hanged on a tripod (in the past, the pots were made of copper) and the ingredients are poured over with cold water, and then the pot is put above an open fire. The fire itself is also very important, because the success of the whole job depends on its intensity. The best fire for fish stew is made of dry and soft Danube wood, such as purple willow or poplar. The dish is never stirred in the pot, but the pot is occasionally swung so that its content is evenly cooked. As for serving, the pot is placed on the table and the dish is served with home-made "yellow" noodles, made of white wheat flower and eggs [67] 


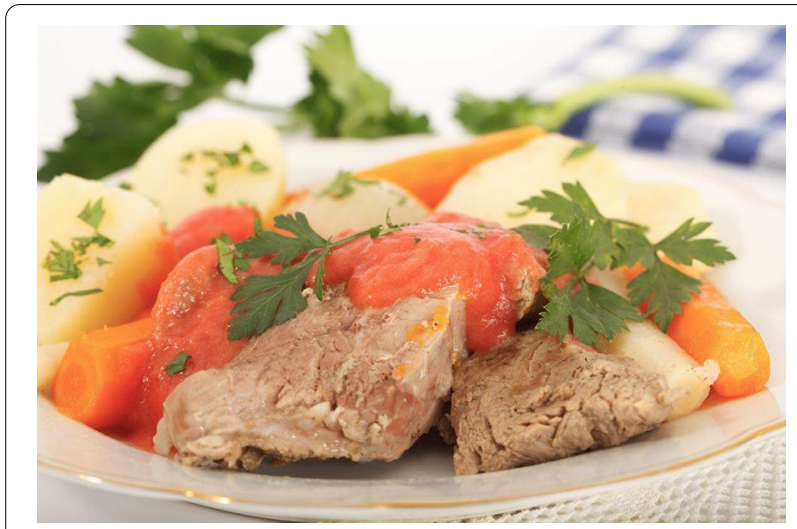

Fig. 6 Rindflajš, a real Vojvodina dish which originates from the German cuisine. In the literal translation from German, rindflajš (Die Rindfleisch) means beef. Rindflajš is made of beef or chicken meat cooked in a soup, and it is most often eaten with horseradish, but in some parts, it is also served with special sauces made of tomato, dill, or sour cherries. Besides the cooked meat, this dish also contains vegetables: potatoes, carrots, and celery [68]

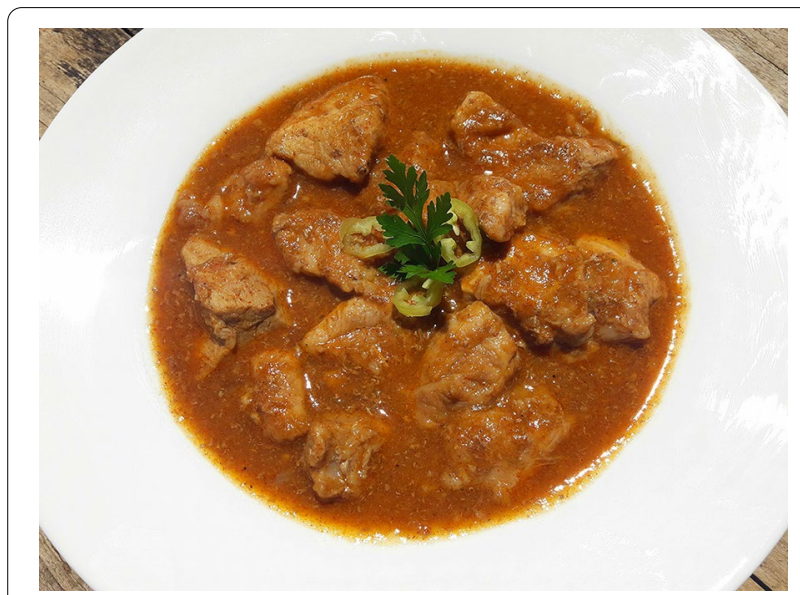

Fig. 7 Perkelt is a traditional Hungarian goulash which has been made for generations in Vojvodina as well (mainly in Bačka), and it is characterized by the richness of taste and smell. Perkelt is a drier variety of goulash that is prepared of meat stewed in thick sauce and with lots of onions. Perkelt is made of veal and pork meat without bones, and the meat is not mashed or strained [69]

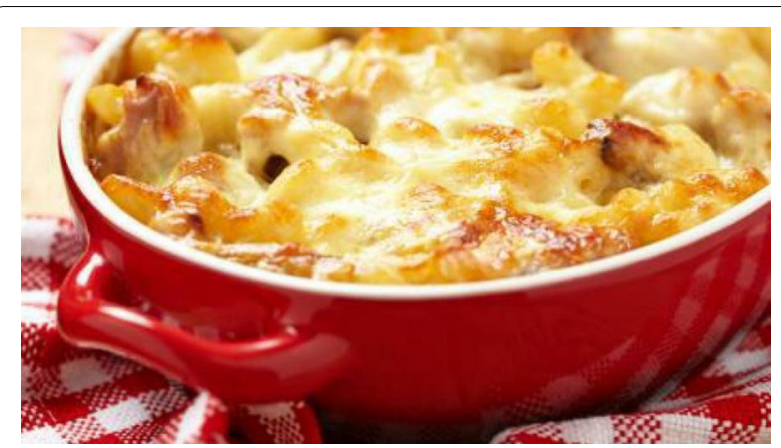

Fig. 8 Curetina sa mlincima (Turkey with pasta tatters). Mlinci (pasta tatters) are traditional Vojvodina type of dough which is made of wheat flour, eggs, water, and salt. It is spread rolled to the thickness of about $1 \mathrm{~mm}$ and then baked in the furnace or on a hot stove top. The turkey meat is cut into chunks, seasoned, and fried. Then it is poured over with the mixture of neutral and sour cream. Along with that, mlinci are broken into pieces and poured over with the hot soup, left for a couple of minutes to absorb the liquid and get softer. Then they are drained and added to the meat and cream. Finally, they are baked in the oven [70]

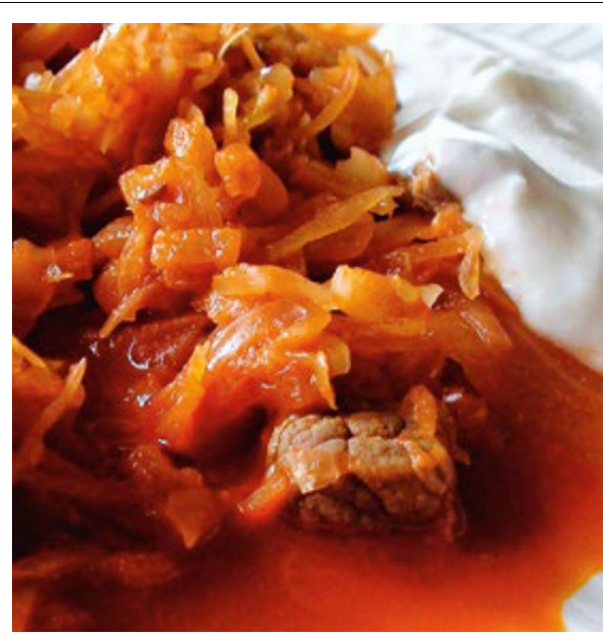

Fig. 9 Sekelji gulaš, Szekely goulash is one of the most famous dishes made of pickled cabbage. It used to represent a traditional winter dish eaten primarily by the poor. There are two stories connected with the origin of this dish. The first one says that the dish was named after Szekely Hungarians who live in today's Romania, while the other story says that the dish was named after Imre Szekely, a city public notary in Budapest. According to the story, Mr Szekely used to have lunch every day in a small restaurant called "Music Clock." One day he came later than usual and, not knowing what to do, the staff collected all the remained cabbage and a few spoons of pork stew. They mixed it, spread it with sour cream, and served it to Mr Szekely. He liked it so much that he asked for the same meal to be prepared again. After the chef and the owner of the restaurant tried the meal, they were convinced that a true specialty was born. This means that this unique Hungarian dish was made purely by accident [4] 


\section{Acknowledgements \\ Not applicable.}

\section{Authors' contributions}

The authors read and approved the final manuscript.

\section{Funding}

The authors received no financial support for the research, authorship, and/or publication of this article.

\section{Availability of data and materials}

Not applicable.

\section{Declarations}

\section{Competing interests}

The authors declare no competing interests.

\section{Author details}

'Department of Geography, Tourism and Hotel Management, Faculty of Sciences, University of Novi Sad, Trg Dositeja Obradovića 3, 21000 Novi Sad, Serbia. ${ }^{2}$ Institute of Sports, Tourism and Service, South Ural State University, 76 Lenin Ave, Chelyabinsk, Russia 454080. ${ }^{3}$ Geographical Institute "Jovan Cvijić" SASA, Djure Jakšića St. 9, 11000 Belgrade, Serbia. ${ }^{4}$ Faculty of Tourism and Hospitality Management, University Singidunum, Danijelova 32, 11000 Belgrade, Serbia.

Received: 11 May 2021 Accepted: 8 August 2021

Published online: 19 August 2021

\section{References}

1. Basarin B, Lukić T, Mesaroš M, Pavić D, Đorđević J, Matzarakis A. Spatial and temporal analysis of extreme bioclimate conditions in Vojvodina. Northern Serbia Int J Climatol. 2018;38(1):142-57. https://doi.org/10. 1002/joc.5166.

2. Statistical Office of the Republic of Serbia. 2011. http://popis2011.stat.rs

3. Radulovački LJ. Ishrana Srba u Sremu. Novi Sad: Matica srpska; 1996.

4. Blešić I, Lazić L, Božin M, Ivkov Džigurski A. Richness of culinary influences: gastronomy of Sombor and Apatin. Novi Sad: Faculty of sciences and Chamber of economy of Vojvodina; 2014.

5. Popov-Raljić J. Ishrana. Novi Sad: Faculty of Sciences, Department of Geography, Tourism and Hotel Management; 2016.

6. Stojanov M. Ej, salaši, salaši-način života i privređivanja. Novi Sad: Matica srpska; 1994.

7. Košić K, Pejanović R, Radović G. Značaj salaša za ruralni turizam Vojvodine. Agroznanje. 2013;14(2):231-40. https://doi.org/10.7251/AGRSR1302231K.

8. Božin M. Turistički gastronomski vodič: Salaši za vas. Novi Sad: Prometej; 2018.

9. Jokić N. Kalorije u svakodnevnom životu. Beograd: Zavod za udžbenike; 2007

10. Vukićević D. Ishrana. Svetozarevo: GP "Novi put"; 1991.

11. Guerrero L, Guàrdia MD, Xicola J, Verbeke W, Vanhonacker F, ZakowskaBiemans S, Sajdakowska M, Sulmont-Rossé C, Issanchou S, Contel M Scalvedi ML. Consumer-driven definition of traditional food products and innovation in traditional foods: a qualitative cross-cultural study. Appetite. 2009;52(2):345-54. https://doi.org/10.1016/j.appet.2008.11.008.

12. Bertozzi L. Tipicidad alimentaria y dieta mediterranea. In: Medina A, Medina F, Colesanti G, editors. El color de la alimentacion mediterranea. Elementos sensoriales y culturales de la nutricion. Barcelona: Icaria; 1998. p. 15-41.

13. Vanhonacker $F$, Lengard V, Hersleth $M$, Verbeke W. Profiling European traditional food consumers. Br Food J. 2010;112(8):871-86. https://doi. org/10.1108/00070701011067479.

14. Amilien $\mathrm{V}$, Hegnes $A W$. The dimensions of 'traditional food' in reflexive modernity: Norway as a case study. J Sci Food Agric. 2013;93(14):3455-63. https://doi.org/10.1002/jsfa.6318.

15. Guerrero L, Claret A, Verbeke W, Enderli G, Zakowska-Biemans S, Vanhonacker F, Issanchou S, Sajdakowska M, Granli BS, Scalvedi L, Contel M.
Perception of traditional food products in six European regions using free word association. Food Qual Prefer. 2010;21(2):225-33. https://doi.org/10. 1016/j.foodqual.2009.06.003.

16. Almli VL, Verbeke W, Vanhonacker F, Næs T, Hersleth M. General image and attribute perceptions of traditional food in six European countries. Food Qual Prefer. 2011;22(1):129-38. https://doi.org/10.1016/j.foodqual. 2010.08.008.

17. Vanhonacker F, Kühne B, Gellynck X, Guerrero L, Hersleth M, Verbeke W. Innovations in traditional foods: impact on perceived traditional character and consumer acceptance. Food Res Int. 2013;54(2):1828-35. https:// doi.org/10.1016/j.foodres.2013.10.027.

18. Lang M. Consumer acceptance of blending plant-based ingredients into traditional meat-based foods: evidence from the meat-mushroom blend. Food Qual Prefer. 2020;79: 103758. https://doi.org/10.1016/j.foodqual. 2019.103758

19. Guerrero L, Claret A, Verbeke W, Sulmont-Rossé C, Hersleth M. Innovation in traditional food products: does it make sense? In: Innovation strategies in the food industry. 2016. p. 77-89. https://doi.org/10.1016/B978-0-12803751-5.00005-2.

20. Amuquandoh FE, Asafo-Adjei R. Traditional food preferences of tourists in Ghana. Br Food J. 2013;115(7):987-1002. https://doi.org/10.1108/ BFJ-11-2010-0197.

21. Promsivapallop P, Kannaovakun P. Factors influencing tourists' destination food consumption and satisfaction: a cross-cultural analysis. APSSR. 2020;20(2):87-105.

22. Fernández-Ferrín P, Calvo-Turrientes A, Bande B, Artaraz-Miñón M, GalánLadero MM. The valuation and purchase of food products that combine local, regional and traditional features: the influence of consumer ethnocentrism. Food Qual Prefer. 2018;64:138-47. https://doi.org/10.1016/j. foodqual.2017.09.015

23. Chanadang S, Chambers E IV. Determination of the sensory characteristics of traditional and novel fortified blended foods used in supplementary feeding programs. Foods. 2019;8(7):261. https://doi.org/10.3390/ foods 8070261

24. Cayot N. Sensory quality of traditional foods. Food Chem. 2007;101(1):154-62. https://doi.org/10.1016/j.foodchem.2006.01.012.

25. Mehfooz T, Ali TM, Arif S, Hasnain A. Effect of barley husk addition on rheological, textural, thermal and sensory characteristics of traditional flat bread (chapatti). J Cereal Sci. 2018;79:376-82. https://doi.org/10.1016/j. jcs.2017.11.020.

26. Yang J, Lee J. Application of sensory descriptive analysis and consumer studies to investigate traditional and authentic foods: a review. Foods. 2019;8(2):54. https://doi.org/10.3390/foods8020054.

27. Blanchet R, Willows $N$, Johnson S, Salmon Reintroduction Initiatives ON, Batal M. Traditional food, health, and diet quality in syilx okanagan adults in British Columbia, Canada. Nutrients. 2020;12(4):927. https://doi.org/10. 3390/nu12040927.

28. Ezzatpanah H. Traditional food and practices for health: Iranian dairy foods. In: Nutritional and health aspects of food in South Asian countries. Academic Press; 2020. p. 275-87.

29. Ruan S, Wang L, Li Y, Li P, Ren Y, Gao R, Ma H. Staple food and health: a comparative study of physiology and gut microbiota of mice fed with potato and traditional staple foods (corn, wheat and rice). Food Funct. 2021;12(3):1232-40. https://doi.org/10.1039/d0fo02264k.

30. Cubillo B, McCartan J, West C, Brimblecombe J. A qualitative analysis of the accessibility and connection to traditional food for aboriginal chronic maintenance hemodialysis patients. Curr Dev Nutr. 2020;4(4):nzaa036. https://doi.org/10.1093/cdn/nzaa036.

31. Steptoe AH, Pollard TM, Wardle J. Development of a measure of the motives underlying the selection of food: the food choice questionnaire. Appetite. 1995;25(3):267-84. https://doi.org/10.1006/appe.1995.0061.

32. Pollard TM, Steptoe AN, Wardle JA. Motives underlying healthy eating: using the Food Choice Questionnaire to explain variation in dietary intake. J Biosoc Sci. 1998;30(2):165-79. https://doi.org/10.1017/S0021 932098001655

33. Januszewska R, Pieniak Z, Verbeke W. Food choice questionnaire revisited in four countries. Does it still measure the same? Appetite. 2011;57(1):94-8.

34. Markovina J, Stewart-Knox BJ, Rankin A, Gibney M, de Almeida MD, Fischer A, Kuznesof SA, Poínhos R, Panzone L, Frewer LJ. Food4Me study: validity and reliability of Food Choice Questionnaire in 9 European 
countries. Food Qual Prefer. 2015;45:26-32. https://doi.org/10.1016/j. foodqual.2015.05.002.

35. Milošević J, Žeželj I, Gorton M, Barjolle D. Understanding the motives for food choice in Western Balkan Countries. Appetite. 2012;58(1):205-14. https://doi.org/10.1016/j.appet.2011.09.012.

36. Dikmen D, İnan-Eroğlu E, Göktaş Z, Barut-Uyar B, Karabulut E. Validation of a Turkish version of the food choice questionnaire. Food Qual Prefer. 2016;52:81-6. https://doi.org/10.1016/j.foodqual.2016.03.016.

37. Cunha LM, Cabral D, Moura AP, de Almeida MD. Application of the Food Choice Questionnaire across cultures: systematic review of cross-cultural and single country studies. Food Qual Prefer. 2018;64:21-36. https://doi. org/10.1016/j.foodqual.2017.10.007.

38. Gama AP, Adhikari K, Hoisington DA. Factors influencing food choices of Malawian consumers: a food choice questionnaire approach. J Sens Stud. 2018;33(5): e12442. https://doi.org/10.1111/joss.12442.

39. Szakály Z, Kontor E, Kovács S, Popp J, Pető K, Polereczki Z. Adaptation of the food choice questionnaire: the case of Hungary. Br Food J. 2018;120(7):1474-88. https://doi.org/10.1108/BFJ-07-2017-0404.

40. Ting H, Tan SR, John AN. Consumption intention toward ethnic food: determinants of Dayak food choice by Malaysians. J Ethn Foods. 2017;4(1):21-7. https://doi.org/10.1016/j.jef.2017.02.005.

41. Wang O, De Steur H, Gellynck X, Verbeke W. Motives for consumer choice of traditional food and European food in mainland China. Appetite. 2015;87:143-51. https://doi.org/10.1016/j.appet.2014.12.211.

42. Pieniak Z, Verbeke W, Vanhonacker F, Guerrero L, Hersleth M. Association between traditional food consumption and motives for food choice in six European countries. Appetite. 2009;53(1):101-8. https://doi.org/10.1016/j. appet.2009.05.019.

43. Eertmans A, Victoir A, Notelaers G, Vansant G, Van den Bergh O. The food choice questionnaire: factorial invariant over western urban populations? Food Qual Prefer. 2006;17(5):344-52. https://doi.org/10.1016/j.foodqual. 2005.03.016.

44. Bessiere J, Tibere L. Traditional food and tourism: French tourist experience and food heritage in rural spaces. J Sci Food Agric. 2013;93(14):3420-5. https://doi.org/10.1002/jsfa.6284.

45. Rachão S, Breda Z, Fernandes C, Joukes V. Food tourism and regional development: a systematic literature review. EJHTR. 2019;21:33-49.

46. Henderson JC. Local and traditional or global and modern? Food and tourism in Singapore. J Gastron Tour. 2016;2(1):55-68. https://doi.org/10 3727/216929716X14546365943494.

47. Blešić I, Pivac T, Božić S. Motives for visiting traditional cultural events of ethnic groups in Vojvodina. In: 4th International scientific conference ToSEE-tourism in southern and eastern Europe 2017" tourism and creative industries: trends and challenges" Opatija, Croatia. Faculty of Tourism and Hospitality Management, University of Rijeka. 2017; p. 43-55.

48. Saaty TL. The analytic hierarchy process. New York: McGraw-Hill Inc; 1980.

49. Harker PT, Vargas LG. The theory of ratio scale estimation: Saaty's analytic hierarchy process. Manag Sci. 1987;33(11):1383-403. https://doi.org/10. 1287/mnsc.33.11.1383.

50. Saaty TL. Decision making for leaders: the analytic hierarchy process for decisions in a complex world. Pittsburgh: RWS Publications; 1992.

51. Siew LW, Wai CJ, Hoe LW. An empirical study on the selection of fast food restaurants among the undergraduates with AHP model. AJIST. 2016;2(3):15-21.

52. Wibowo SW, Tielung M. Analytical Hierarchy Process (AHP) approach on consumer preference in franchise fast food restaurant selection in Manado City (Study At: Mcdonald's, Kfc, and A\&W). Jurnal EMBA: Jurnal
Riset Ekonomi, Manajemen, Bisnis dan Akuntansi. 2016;4(2):22-8. https:// doi.org/10.35794/emba.v4i2.12490.

53. Fibri DL, Frøst MB. Consumer perception of original and modernised traditional foods of Indonesia. Appetite. 2019;133:61-9. https://doi.org/ 10.1016/j.appet.2018.10.026.

54. Goral R. Prioritizing the factors which affect the selection of hotels by consumers traveling for vacation with analytical hierarchy process (AHP) method. J Tour Manag Res. 2020;7(1):11-31. https://doi.org/10.18488/ journal.31.2020.71.11.31.

55. Yasami M, Promsivapallop P, Kannaovakun P. Food image and loyalty intentions: Chinese tourists' destination food satisfaction. JCTR. 2020;2:121. https://doi.org/10.1080/19388160.2020.1784814.

56. Fang J, Partovi FY. Criteria determination of analytic hierarchy process using a topic model. Expert Syst Appl. 2020;169: 114306. https://doi.org/ 10.1016/j.eswa.2020.114306.

57. Saaty TL. How to make a decision: the analytic hierarchy process. Eur $J$ Oper Res. 1990;48(1):9-26. https://doi.org/10.1016/0377-2217(90)90057-I.

58. Cheng EWL, Li H. Construction partnering process and associated critical success factors: quantitative investigation. J Manag Eng. 2002;18(4):194202. https://doi.org/10.1061/(asce)0742-597x(2002)18:4(194).

59. Ossadnik W, Schinke S, Kaspar RH. Group aggregation techniques for analytic hierarchy process and analytic network process: a comparative analysis. Group Decis Negot. 2016;25(2):421-57. https://doi.org/10.1007/ s10726-015-9448-4.

60. Kaiser HF. An index of factorial simplicity. Psychometrika. 1974;39:31-6. https://doi.org/10.1007/BF02291575.

61. Nunnally JC. Psychometric theory. New York: McGraw-Hill; 1978.

62. Verbeke W. Impact of communication on consumers' food choices: plenary lecture. Proc Nutr Soc. 2008;67(3):281-8. https://doi.org/10.1017/ S0029665108007179.

63. Fotopoulos C, Krystallis A, Vassallo M, Pagiaslis A. Food Choice Questionnaire (FCQ) revisited. Suggestions for the development of an enhanced general food motivation model. Appetite. 2009;52(1):199-208. https:// doi.org/10.1016/j.appet.2008.09.014

64. Gagić S, Jovičić A, Erdeji I, Kalenjuk B, D Petrović M. Analiza kvaliteta u vojvođanskim restoranima. Zbornik radova, Konkurentnost turističke destinacije, Beograd, Srbija, 2015.

65. Maina JW. Analysis of the factors that determine food acceptability. TPI J. 2018;7(5):253-7.

66. Namkung Y, Jang S. Does food quality really matter in restaurants? Its impact on customer satisfaction and behavioral intentions. J Hosp Tour Res. 2007;31(3):387-409. https://doi.org/10.1177/1096348007299924.

67. Riblji paprikaš [Internet]. [cited 2021 April 2]. https://www.ravnoplov.rs/ riblji-paprikas-kultno-jelo-gornjeg-podunavlja.

68. Rindflajš [Internet]. [cited 2021 April 2]. https://lepaisrecna.mondo.rs/ Recepti/Recepti-ostalo/a28896/RINFLAJS-JEPRAVI-SPECIJALITET-IZ-VOJVO DINE-kuvano-meso-i-povrce-u-sosu-od-paradajzaprijaju-stomakuRECEPT.html.

69. Perkelt. [Internet]. [cited 2021 April 3]. https://ukusivojvodine.rs/perkelt/.

70. Ćretina sa mlincina. [Internet]. [cited 2021 April 2]. http://nedeljnikafera. net/tradicionalno-vojvodjansko-jelo-potpuno-ozivelo-curetina-sa-mlinc ima-zagospodarila-restoranskim-kuhinjama-ali-i-domovima-gurmana/.

\section{Publisher's Note}

Springer Nature remains neutral with regard to jurisdictional claims in published maps and institutional affiliations. 